\begin{tabular}{|l|l|}
\hline $\begin{array}{l}\text { 2. To: (Receiving Organization) } \\
\text { Distribution }\end{array}$ & $\begin{array}{l}\text { 3. From: (Originating Organization) } \\
\text { Process Engineering Analysis }\end{array}$ \\
\hline 5. Proj./Prog./Dept./Div.: & 6. Cog. Engr.: \\
TWRS & T. J. Bander \\
\hline
\end{tabular}

8. Originator Remarks:

Approval/Release

11. Receiver Remarks:
4. Related EDT Ho.:

$N / A$

7. Purchase Order No.:

$N / A$

9. Equip./Component No.:

$N / A$

10. System/Bldg./Facility:

$N / A$

12. Major Assm. Dwg. No.: N/A

13. Permit/Permit Application Na.: $N / A$

14. Required Response Date: $6 / 14 / 96$

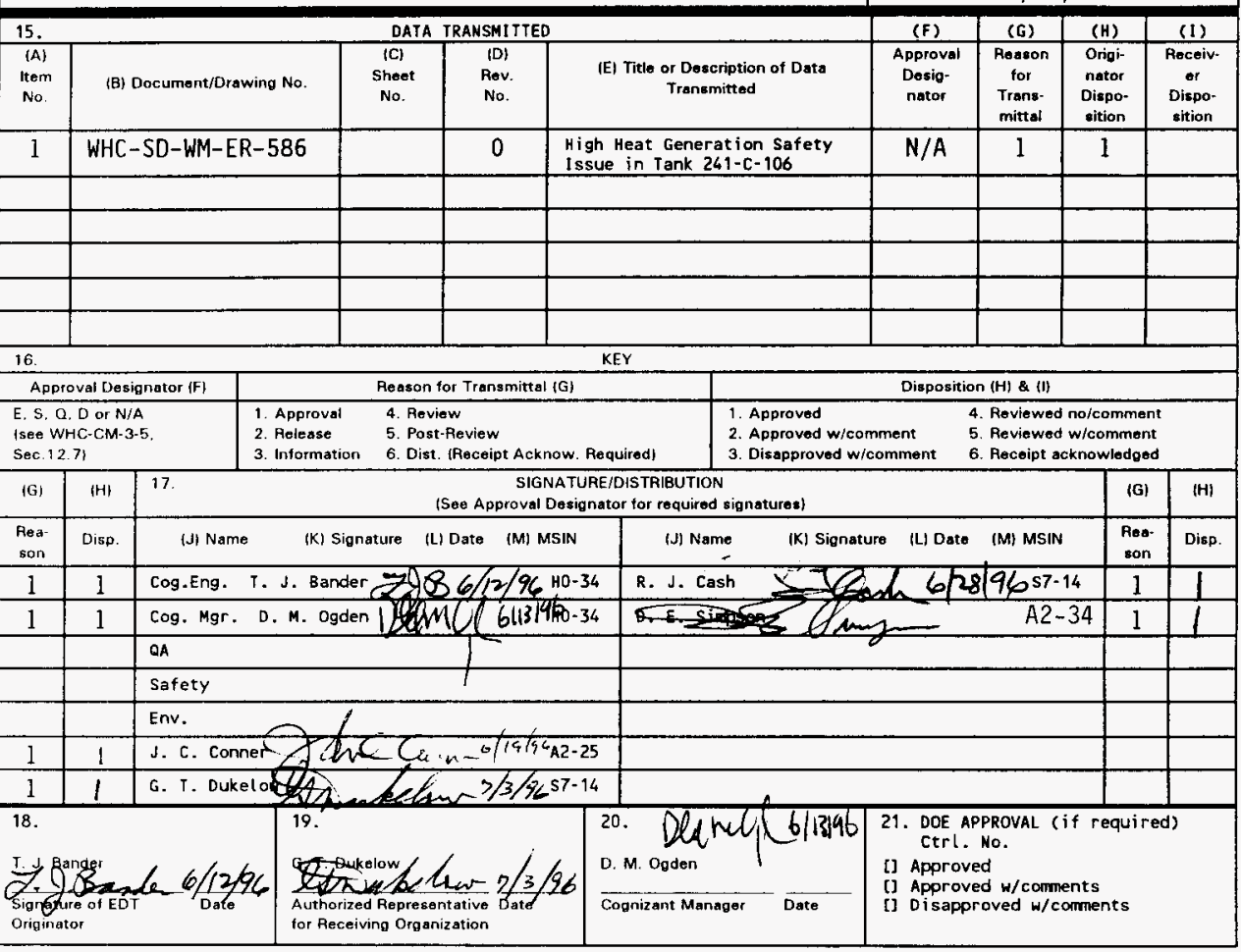

BD-7400-172-2(04/94) GEF097 


\section{High Heat Generation Safety Issue in Tank 241-C-106}

\section{T. J. Bander}

Westinghouse Hanford Company, Richland, WA 99352

U.S. Department of Energy Contract DE-AC06-87RL10930

EDT/ECN: 614680

UC: 2020

Org Code: 74A50

Charge Code: N2219

B\&R Code: EW3135040

Total Pages: 9

Key Words: Tank 241-C-106, High Heat, Safety Issue

Abstract: A "White" paper was written on the High Heat Generation Safety Issue in Tank 241-C-106. The issue is if tank 241-C-106 should start leaking, the lack of alternative cooling methods will require continued addition of water and thereby possibly increase the amount of leakage to the ground. If the current methods of cooling the tank are stopped, the sludge and concrete structure will heat to temperatures greater than established limits and may cause structural damage, leading to dome collapse and possibly an unacceptable radioactive release to the environment. Potential approaches to the resolution of this issue were evaluated, and waste retrieval by sluicing and transfer to a doubleshell tank was selected. The paper gives background information on the tank and an assessment of the issue and its resolution, with references to support the paper.

TRADEMARK DISCLAIMER. Reference herein to any specific comercial product, process, or service by trade name, trademark, manufacturer, or otherwise, does not necessarily constitute or imply its endorsement, recommendation, or favoring by the United States Government or any agency thereof or its contractors or subcontractors.

Printed in the United States of America. To obtain copies of this document, contact: WHC/BCS Document Control Services, P.O. Box 1970, Mailstop H6-08, Richland WA 99352, Phone (509) 372-2420; Fax (509) $376-4989$
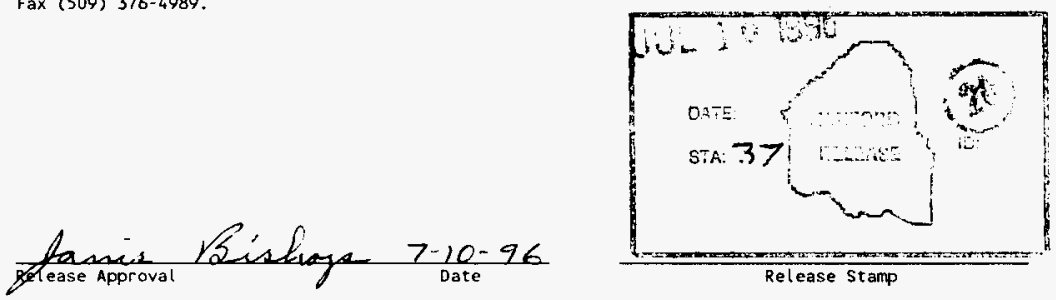


\title{
HIGH HEAT GENERATION SAFETY ISSUE IN TANK 241-C-106
}

\author{
June 1996
}

Prepared By: $\frac{8.8 \text { Bandez }}{\begin{array}{l}\text { T. J. Bander, Principal Engineer } \\ \text { Process Engineering Analysis }\end{array} \text { Date: } 6 / 13 / 96}$

Approved By: Dol MOC Date: $6 / 25196$

D. M. Ogden, Manager

Process Engineering Analysis 
WHC-SD-WM-ER-586, Rev. 0

\section{CONTENTS}

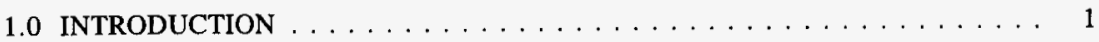

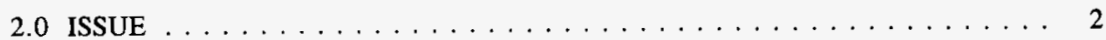

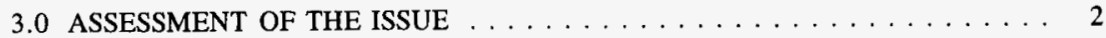

4.0 ISSUE RESOLUTION $\ldots \ldots \ldots \ldots \ldots \ldots \ldots \ldots \ldots \ldots \ldots \ldots$

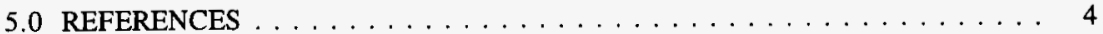




\section{HIGH HEAT GENERATION SAFETY ISSUE IN TANK 241-C-106}

\subsection{INTRODUCTION}

The addition of cooling water to Hanford Site waste tank 241-C-106 has been identified as a safety issue. In January 1991, in accordance with Public Law 101-510, Section 3137 (the Wyden Amendment), tank 241-C-106 was identified as a Watch List Tank. This is the only Hanford Site tank identified as a safety issue High Heat Watch List tank (Harmon 1991), and is the only tank that requires water additions for cooling.

Tank 241-C-106 is a 2.0-million-liter (530,000-gallon)-capacity single-shell tank 23 meters ( 75 feet) in diameter located in C Farm in the 200 East Area. Tank 241-C-106 has been used for radioactive waste storage since mid-1947 and currently contains about 870,000 liters $(230,000$ gallons) of waste. During the late 1960 s, a program to recover strontium and cesium from aging waste was instituted at the Hanford Site. During the sludge washing and decanting steps in the recovery process, heat-generating, strontium-rich sludge was unintentionally transferred to tank 241-C-106.

Since mid-1971, water has been added periodically to the tank in order to keep the sludge wet and promote heat transfer by evaporation to the tank headspace. Tank 241-C-106 was placed on inactive status in 1979 and is currently categorized as sound (i.e., not leaking). The operating liquid level since 1981 has been nominally between 190 and 200 centimeters ( 75 and 79 inches), although on rare occasions the level has dropped to 189 centimeters ( 74.5 inches).

Recent computer studies (Bander 1995 and Fryer and Thurgood 1995) concluded that the current heat generation rate (about $117,000 \pm 15,000$ British thermal units per hour) is too high to eliminate the current means of cooling tank 241-C-106 without providing an alternative, such as partial waste retrieval or an alternate means of cooling. A Tri-Party Agreement milestone has been established to initiate partial waste retrieval of tank 241-C-106, using the sluicing method, to resolve the high-heat safety issue and demonstrate waste retrieval technology. The milestone due date is October 31, 1997. 


\subsection{ISSUE}

If tank 241-C-106 were to start leaking, the lack of alternative cooling methods would require continued addition of water and thereby possibly increase the amount of leakage to the ground. If the current methods of cooling the tank (evaporation and ventilation) are stopped, the sludge and the concrete tank structure will heat to temperatures greater than established limits and may incur structural damage, leading to tank dome collapse and possibly a radioactive release to the environment.

\subsection{ASSESSMENT OF THE ISSUE}

Radiochemical analyses of several tank 241-C-106 core samples (Weiss 1987, Pauly and Torgerson 1987, Bratzel 1980, Horton 1977, and Koegler 1976) have been used to estimate the heat load in the tank (Bander 1993a). A study was done in 1987 (Pauly and Torgerson 1987) to identify any problems associated with the future stabilization of the tank and to identify possible solutions.

The exhauster fan on the tank 241-C-106 ventilation system was out of service from January 25, 1992 to June 7, 1992. During that time, no heat was removed from the tank by the ventilation system, thus providing data for calibrating a thermal model (Bander 1993b). Even though no water additions were made during the ventilation system outage, the surface level of the waste increased. This phenomenon indicates that more of the central bottom sludge region reached the local saturation temperature and an increase in the number and size of steam voids in the bottom of the tank occurred. During sluicing retrieval, movement of bottom sludge that is above the saturation temperature (corresponding to atmospheric pressure) could produce a thermal bump (Thurgood et al. 1995).

A process test was initiated in tank 241-C-106 to decrease the liquid level in order to minimize the environmental impact of a tank leak, as well as to establish a lower minimum operating level to reduce corrosion potential in the tank liner. Analyses (Bander and Thurgood 1995) indicated that the tank liquid level can be operated between 183 and 188 centimeters ( 72 and 74 inches) with little effect on the removal of heat from the tank. The process test was initiated March 10,1994. Water addition to the tank was temporarily discontinued to allow the liquid level to decrease, through evaporation, at a rate of approximately 5 to 8 centimeters ( 2 to 3 inches) per month $(20,800$ to 31,400 liters [5,500 to 8,300 gallons] per month). The test ended June 15,1994 with the liquid level estimated at $174 \mathrm{~cm}$ ( $68.5 \mathrm{in}$.). Water additions resumed on June 17, 1994 to bring the liquid level to its normal operating range. Tank 241-C-106's thermal-hydraulic behavior during and following the process test was evaluated in several reports (Bander 1995 and Thurgood et al. 1995). The analyses indicated that the volume of steam voids increased during the process test. 
A structural integrity evaluation for in situ conditions in tank 241-C-106 was completed in 1994 (Julyk 1994). This evaluation included a historical review of related design documents, a thermal-history simulation, a material-property degradation simulation, and an assessment of structural capacity as measured against project-specific structural acceptance criteria. The evaluation studies confirmed the continuing need for active cooling (water additions with forced ventilation) of the wastes currently in tank 241-C-106.

\subsection{ISSUE RESOLUTION}

Potential approaches to resolution of the tank 241-C-106 high heat generation issue were evaluated, and waste retrieval by sluicing and transfer to a double-shell tank was selected. After partial removal of the strontium, which is the main heat source, the tank can be interim stabilized (term applied to a tank that contains less than 190,000 liters [50,000 gallons] of drainable interstitial liquid and less than 19,000 liters [5,000 gallons] of supernatant liquid). If all sluiceable sludge (estimated to be 85 percent of the waste in the tank) is removed, the dry waste (waste with no interstitial liquid) can be maintained below operating specification document (OSD) temperature limits without evaporative cooling and with only passive ventilation (Crea 1996). If 75 percent of the waste is removed and as much as 50 percent of the heat load remains in the tank, then temperatures can be maintained below the OSD limits without evaporative cooling, provided the ventilation is maintained at the current level of 65 cubic meters per minute $(2,300$ cubic feet per minute). Analyses also show (Crea 1996) that using the best estimates of heat load distribution and dry waste thermal conductivity, only 90 centimeters ( 3 feet) of waste needs to be removed for tank temperatures to be maintained below OSD temperature limits with the current ventilation of 65 cubic meters per minute $(2,300$ cubic feet per minute).

To prevent steam bubbles from forming, growing and possibly collapsing (causing a thermal bump) when the waste is disturbed by sluicing, it is necessary, before waste is removed from the tank, to reduce or eliminate the region in the bottom of tank 241-C-106 that is above the saturation temperature. Installation of a chiller will maintain waste temperatures below the local saturation temperature (Thurgood and Ogden). A contingency chiller system design (Rensink and Kriskovich 1995b) was developed for Tank Waste Remediation System (TWRS) Safety Engineering as part of a comprehensive cooling design (Rensink and Kriskovich 1995a).

Retrieval of the waste in tank 241-C-106 by sluicing will be accomplished through Project W-320. A contingency chiller system will not be needed to maintain waste temperatures below the local saturation temperature once the installation of Project W-320's chiller is completed. The chiller system for Project W-320 has been developed and will be available for cooling in July 1996.

Analyses were conducted to determine the rate at which the waste can be removed from tank 241-C-106 (Bander et al. 1996). The main concern is to maintain the waste 
temperature below the local saturation temperature. Because the saturation temperature decreases as the depth of the waste decreases, the sluicing must be done in stages to allow the chiller system to cool the waste below the saturation temperature. The effects of the operation of pumps in the sluicing system are also included in these analyses. The recommended sluicing scenario is to sluice 30 to 60 centimeters ( 1 to 2 feet) of sludge and stop for a period of two weeks before continuing (Bander et al. 1996).

Tank 241-AY-102 has been selected to receive the waste taken out of tank 241-C-106. An analysis (Sathyanarayana and Fryer 1996) shows that tank 241-AY-102 can be operated below operating requirement temperature limits following waste transfer. A safety assessment for the tank 241-C-106 waste removal operation is being prepared (Conner 1996). The sluicing operation is planned to begin in October 1996 and be completed sometime in 1997.

\subsection{REFERENCES}

Bander, T. J., 1993a, Thermal History of Tank 241-C-106, WHC-SD-WM-ER-161, Rev. 0, Westinghouse Hanford Company, Richland, Washington.

Bander, T. J., 1993b, Revised Thermal History of Tank 241-C-106, WHC-SD-WM-ER-200, Rev. 0, Westinghouse Hanford Company, Richland, Washington.

Bander, T. J., 1995, Tank 241-C-106 Process Test Report, WHC-SD-WM-ER-427, Rev. 0, Westinghouse Hanford Company, Richland, Washington.

Bander, T. J., B. A. Crea, and D. M. Ogden, 1996, Tank 241-C-106 Sluicing Evaluation, WHC-SD-WM-ER-588, Rev. 0, Westinghouse Hanford Company, Richland, Washington.

Bander, T. J., and M. J. Thurgood, 1995, Tank 241-C-106 Thermal Hydraulic Analysis to Establish the Cooling Liquid at a Minimum Level, WHC-SD-WM-ER-495, Rev. 0, Westinghouse Hanford Company, Richland, Washington.

Bratzel, D. R., 1980, Evaluation of Waste Tank Physical and Chemical Characterization Data, (internal letter 65453-80-265 to F. M. Jungfleisch, September 18), Rockwell International, Richland, Washington.

Conner, J. C., 1996, Safety Assessment for Tank 241-C-106 Waste Retrieval, Project W-320, WHC-SD-WM-SAD-024, Rev. 0. Westinghouse Hanford Company, Richland, Washington. 
Crea, B. A., T. J. Bander, and D. M. Ogden, 1996, Tank C-106 Heat Distribution and Post Sluicing Temperatures, (internal memorandum 74A50-96-BAC-006 to R. J. Cash, February 27), Westinghouse Hanford Company, Richland, Washington.

Fryer, B. C., and M. J. Thurgood, 1995, Revised Tank Heat Load Estimate for Tank C-106 Based on GOTH Analysis of the Process Test, JMI-9503-04, John Marvin, Inc., Richland, Washington.

Harmon, H. D., 1991, Safety Measures for Waste Tanks at Hanford Site, Richland, Washington, (Letter Number 9059124 to R. E. Gerton, DOE-RL, January 8), Westinghouse Hanford Company, Richland, Washington.

Horton, J. E., 1977, Characterization and Analysis of Tank 106-C, (internal letter to W. R. Christensen, July 22), Rockwell International, Richland, Washington.

Julyk, L. J., 1994, Tank 241-C-106 Structural Integrity Evaluation for In Situ Conditions, WHC-SD-W320-ANAL-001, Rev. 0, Westinghouse Hanford Company, Richland, Washington.

Koegler, S. S., 1976, A and AX Tank Sludge Heat Generation Rates, (internal letter to R. E. Felt, February 12), Atlantic Richfield Hanford Company, Richland, Washington.

Pauly, T. R., and M. M. Torgerson, 1987, Tanks 105-C and 106-C Stabilization Study, RHO-RE-EV-97, Rockwell Hanford Operations, Richland, Washington.

Public Law 101-510, Section 3137, 1990, Safety Measures for Waste Tanks at Hanford Nuclear Reservation, U.S. Congress, Washington, D.C. [Also referred to as the Wyden Amendment]

Rensink, G. E., and J. R. Kriskovich, 1995a, Waste Tank 241-C-106 Comprehensive Cooling Design Summary Report, WHC-SD-WM-RPT-104, Rev. 0, Westinghouse Hanford Company, Richland, Washington.

Rensirk, G. E., and J. R. Kriskovich, 1995b, Contingency Chiller System Design Report for Tank 241-C-106, WHC-SD-WM-RPT-162, Rev. 0, Westinghouse Hanford Company, Richland, Washington.

Sathyanarayana, K., and B. C. Fryer, 1996, Thermal Hydraulic Evaluation of Consolidating Tank C-106 Waste into AY-102, WHC-SD-WM-ER-534, Rev. 0, Westinghouse Hanford Company, Richland, Washington.

Thurgood, M. J., B. C. Fryer, D. M. Ogden, and K. Sathyanarayana, 1995, Goth Tank C-106 Thermal Hydraulics Analysis Related to the 1994 Process Test, NAI-940708-3, Numerical Applications, Inc., Richland, Washington. 
Thurgood, M. J., and D. M. Ogden, 1995, Tank C-106 Contingency Chiller System Analysis, WHC-SD-WM-ER-457, Rev. 0, Westinghouse Hanford Company, Richland, Washington.

Weiss, R. L., 1987, Additional Analyses on Core Samples from Tanks 214-C-105 and 241-C-106, (internal letter 65-453-87-050a to T. R. Pauly, May 27), Rockwell International, Richland, Washington. 


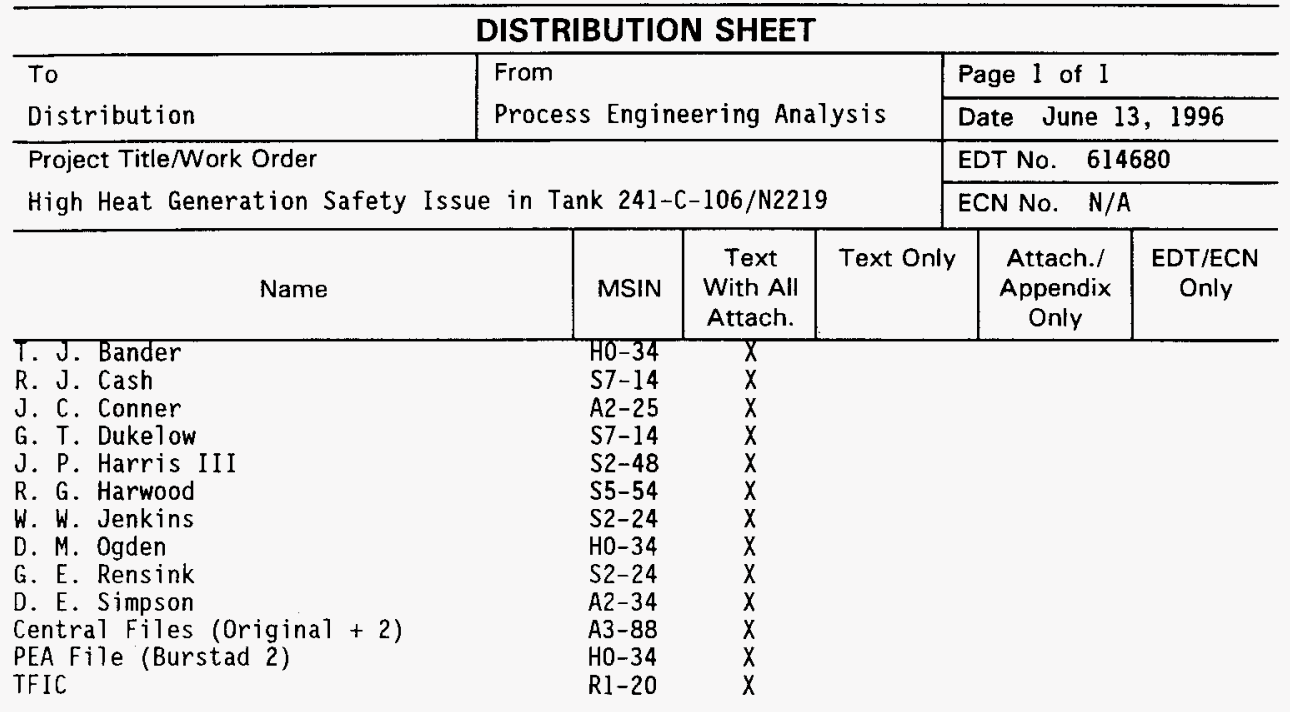

